\title{
Need of Calcium and Vitamin D in Patients after a Recent Fracture
}

\author{
Joop J. P. W. van den Bergh ${ }^{1,2,3,4}$, Sakineh Shab Bidar ${ }^{5}$, Sandrine Bours ${ }^{3}$, Tineke A. C. M. van Geel ${ }^{6,7}$, \\ Piet P. M. M. Geusens ${ }^{3,4,7}$ \\ ${ }^{1}$ VieCuri MC Noord Limburg, Venlo, The Netherlands; ${ }^{2}$ Nutrim School for Nutrition, Toxicology and Metabolism, Maastricht, The \\ Netherlands; ${ }^{3}$ Department of Internal Medicine, Subdivision Rheumatology, Maastricht University Medical Centre, Maastricht, The \\ Netherlands; ${ }^{4}$ Biomedical Research Center, University Hasselt, Hasselt, Belgium; ${ }^{5}$ Department of Nutrition and Biochemistry, \\ School of Public Health and Institute of Public Health Research, Tehran University of Medical Science, Tehran, Iran; ${ }^{6}$ Department of \\ General Practice, Maastricht University, Maastricht, The Netherlands; ${ }^{7}$ CAPHRI, Maastricht University, Maastricht, The Netherlands. \\ Email: jvdbergh@hetnet.nl
}

Received January $4^{\text {th }}, 2011$; revised March $5^{\text {th }}, 2012$; accepted March $13^{\text {th }}, 2012$

\begin{abstract}
Adequate calcium and vitamin D intake is advocated in guidelines of osteoporosis. However, the dosage needed to achieve an optimal calcium intake and vitamin D status is still a point of debate. Of 902 consecutive patients older than 50 years presenting at the time of fracture, 502 were evaluable for measurement of calcium intake and serum $25(\mathrm{OH}) \mathrm{D}$ concentration. We calculated the percentage of patients who needed calcium supplements to achieve intake of $\geq 1000$ $\mathrm{mg} / \mathrm{d}$ and who needed cholecalciferol supplementation to achieve serum levels of $\geq 50 \mathrm{nmol} / \mathrm{l}$. Calcium intake ranged between 250 and $2050 \mathrm{mg} / \mathrm{d}$ and serum 25(OH)D between $<10$ and $130 \mathrm{nmol} / \mathrm{l}$. A combination of calcium intake of $\geq 1000 \mathrm{mg} / \mathrm{d}$ and serum $25(\mathrm{OH}) \mathrm{D}$ concentration of $\geq 50 \mathrm{nmol} / 1$ was present in $11 \%$ of patients. To achieve $1000 \mathrm{mg} / \mathrm{d}$ of calcium, $57 \%$ of patients needed supplementation of $500 \mathrm{mg} / \mathrm{d}$ and $12 \%$ needed $1000 \mathrm{mg} / \mathrm{d}$. Systematic calcium supplements of $500 \mathrm{mg} / \mathrm{d}$ would achieve an intake of $1000 \mathrm{mg} / \mathrm{d}$ in $88 \%$. To achieve serum $25(\mathrm{OH}) \mathrm{D}$ concentrations of 50 nmol/l, $41 \%$ of patients needed a supplement of $800 \mathrm{IU}$ D3/d and $25 \%$ needed higher doses. Systematic supplementation of $800 \mathrm{IU} / \mathrm{d}$ would achieve $50 \mathrm{nmol} / \mathrm{l}$ in $75 \%$ of patients. Calcium intake and vitamin D status vary considerably between fracture patients. Conclusion: calcium supplements need to be titrated individually to achieve desirable levels. Most patients achieved $50 \mathrm{nmol} / 1$ of $25(\mathrm{OH}) \mathrm{D}$ with $800 \mathrm{IU} \mathrm{D} 3 / \mathrm{d}$. Prospective studies are needed to study how to achieve and maintain optimal serum vitamin $\mathrm{D}$ levels and adequate calcium intake.
\end{abstract}

Keywords: Fracture; Osteoporosis; Secondary Fracture Prevention; Calcium Supplementation; Vitamin D Supplementation

\section{Introduction}

Patients older than 50 years presenting with a fracture have an increased risk for subsequent fracture, which is highest during the first years after a fracture [1-8]. Therefore, medical therapy is advocated in fracture patients at high risk of subsequent fractures, including drug therapy and adequate intake of calcium and vitamin D [9-13]. Regardless of fracture history, calcium intake is low in subjects older than 50 years, in the elderly and in patients with osteoporosis [14-16]. Vitamin D insufficiency (serum $25(\mathrm{OH}) \mathrm{D}$ concentration $<50 \mathrm{nmol} / \mathrm{l})$ is endemic worldwide [17] and is frequently present in patients with osteoporosis, with or without a fracture [18-31]. There is large heterogeneity in the medical literature about the clinical approach to determine the need and amount of calcium and vitamin D supplements [9-34]. Clinical trials with fracture prevention as endpoint used variable doses of calcium $(0-1500 \mathrm{mg} / \mathrm{d})$ and vitamin D supplements (250 - $1200 \mathrm{IU} / \mathrm{d})$, in some studies at fixed doses and in other studies according to baseline levels [35-37]. In guidelines on osteoporosis, the clinical standard for measuring the need of calcium is to evaluate calcium intake (such as by interview or standard questionnaires) [9-13,35-37]. A total calcium intake of at least 900 $1500 \mathrm{mg} / \mathrm{d}$ is advocated to be achieved by diet or by calcium supplementation when necessary $[9-13,20-22$, 27-31]. In these guidelines, the upper limit of advised calcium intake varies, as far as mentioned, between 1200 and $2500 \mathrm{mg} / \mathrm{d}[12,22,27]$. All osteoporosis guidelines advocate fixed supplements between 400 and $1200 \mathrm{IU}$ D3/d [9-13]. In addition, one guideline advocates measurement of serum levels of 25-hydroxyvitamin D (25 $(\mathrm{OH}) \mathrm{D})$ in elderly when osteomalacia or when vitamin $\mathrm{D}$ deficiency is suspected [12]. Desirable serum levels of 
25(OH)D is not mentioned in one guidelines[11], or specified in others as 50,75 or $80 \mathrm{nmol} / 1$ [9-13]. In the context of fall prevention and prevention of non-vertebral fractures, even serum levels of $100 \mathrm{nmol} / \mathrm{l}$ are considered as desirable levels [32-34,38]. There appears to be no evidence that it would be beneficial to increase serum 25(OH)D levels above $150 \mathrm{nmol} / \mathrm{l}$ [30]. In terms of safety, a vitamin D intake of $2000 \mathrm{IU} / \mathrm{d}[22,32-34,38]$, and even up to $10.000 \mathrm{IU} / \mathrm{d}$ is considered as safe $[38,39]$. In terms of serum concentrations of $25(\mathrm{OH}) \mathrm{D}$, the upper limit of safety is $220 \mathrm{nmol} / 1[33,38]$ or even $374 \mathrm{nmol} / 1$ [40]. It takes approximately two to three months to achieve desired serum levels, [40] but the exact relation between specific dosing regimens of vitamin $\mathrm{D}$ supplements and the timing needed to achieve desired levels is unclear $[30,38]$. We evaluated the calcium intake and serum $25(\mathrm{OH}) \mathrm{D}$ levels in patients at the time they presented with a fracture and calculated the supplements needed to achieve desirable levels, taking into account upper safety levels.

\section{Methods}

Of the 902 consecutive patients, who were enrolled in a study to evaluate the prevalence of contributors to secondary osteoporosis, 502 were available for prospectively planned evaluation (Figure 1).

Patients known to have an active malignancy or recent chemotherapy, end-stage renal disease, high-impact trauma, need for critical care services, a history of gastrictomy, small bowel resection and eating disorders $(\mathrm{n}=10)$ were excluded. Other reasons for non-participation were not being able to show up at the measurements or no interest in fracture risk evaluation $(\mathrm{n}=237)$, no results of serum calcium $(\mathrm{n}=20)$ or $25(\mathrm{OH}) \mathrm{D}(\mathrm{n}=2)$, primary $(\mathrm{n}=$ 17) or idiopathic hyperparathyroidism $(n=8)$ (serum PTH was measured in all), hypercalciuria $(n=4)($ calciuria was measured on indication in 16 patients) and non-response to calcium questionnaire $(\mathrm{n}=102)$. Dietary calcium intake was ascertained from a food frequency

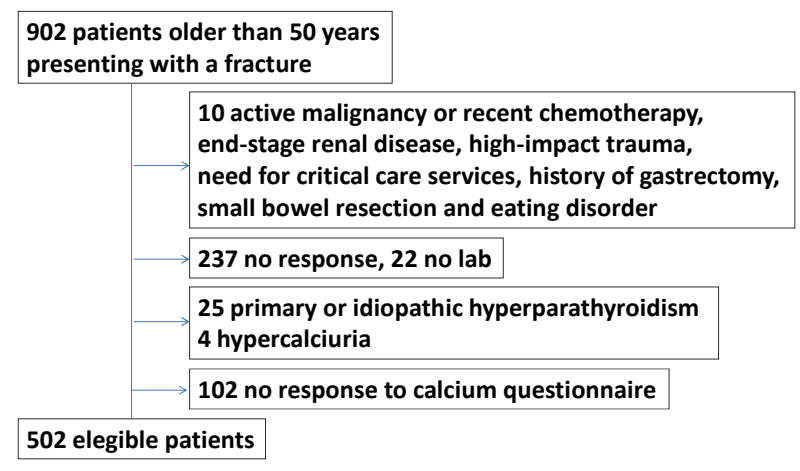

Figure 1. Flow chart of included patients presenting with a fracture. questionnaire completed by the subjects and then reviewed by the physician during the office visit. Total calcium intake was calculated as average daily dietary calcium intake from this questionnaire plus $250 \mathrm{mg} / \mathrm{d}$ as standard intake from background diet [12]. Serum $25(\mathrm{OH}) \mathrm{D}$ concentration was measured immunochemically using the LIASON $^{\circledR}$ assay (DiaSorin, Saluggia, Italy). Bone mineral density (BMD) in the left or right hip and the lumbar spine was determined using dual Xray absorptiometry (DXA) with the Hologic QDR 4500 (Hologic Discovery Corp, Waltham, MA, US). Diagnosis of osteoporosis was based on the criteria of the World Health Organization (WHO) for BMD [41] as provided by the manufacturer for women and men [41].

Fractures were grouped in hip, major (clinical vertebra, pelvis, distal femur, proximal tibia, multiple rib, and proximal humerus), minor (all remaining fractures, excluding fingers and toes) and fingers and toes [1].

We analyzed the effects of several doses of calcium supplementation $(500$ and $1000 \mathrm{mg} / \mathrm{d}$ ) and of vitamin D supplementation $(400,800,1200,1600,2000$ and 2400 IU D3/d), as currently available in the Netherlands for daily practice.

Based on the baseline calcium intake, we calculated the percentage of patients who needed individualized doses of $500 \mathrm{mg} / \mathrm{d}$ or $1000 \mathrm{mg} / \mathrm{d}$ of calcium to achieve a total calcium intake of 1000 or $1200 \mathrm{mg} / \mathrm{d}$. Based on baseline serum levels of $25(\mathrm{OH}) \mathrm{D}$, we calculated the percentage of patients who needed $800 \mathrm{IU} / \mathrm{d}$ or more of vitamin D supplements to achieve serum levels of $25(\mathrm{OH}) \mathrm{D}$ of 50 or $75 \mathrm{nmol} / \mathrm{l}$, taking into account that serum levels would raise by $1.2 \mathrm{nmol} / 1$ per $40 \mathrm{IU} / \mathrm{d}$ if baseline $25(\mathrm{OH}) \mathrm{D}$ levels are $<50 \mathrm{nmol} / \mathrm{l}$ [38]. We furthermore analyzed the effects of systematic supplementation of several fixed doses of calcium and vitamin D supplements to all patients. We calculated the percentage of patients who would surpass the upper limit of safety when using individualized and systematic fixed doses (defined as a calcium intake $>1500 \mathrm{mg} / \mathrm{d}$ [12] and serum concentrations of $25(\mathrm{OH}) \mathrm{D}>220 \mathrm{nmol} / \mathrm{l})$. Multivariable analysis was performed to investigate whether age, sex, BMD and fracture location at baseline were related to baseline calcium intake or baseline serum levels of 25 $(\mathrm{OH}) \mathrm{D}$. ANOVA was used for analysis of seasonal variations in term levels of serum $25(\mathrm{OH}) \mathrm{D}$ concentrations.

\section{Results}

Baseline characteristics of fracture patients are shown in Table 1.

Mean calcium intake was $839 \mathrm{mg} / \mathrm{d}$ (range 250 - 2050 $\mathrm{mg} / \mathrm{d}$ ) and mean serum 25(OH)D concentration was 43 $\mathrm{nmol} / \mathrm{l}($ range $<10$ to $130 \mathrm{nmol} / \mathrm{l})$. The combination of a 
calcium intake of $\geq 1000 \mathrm{mg} / \mathrm{d}$ and a serum $25(\mathrm{OH}) \mathrm{D}$ concentration of $\geq 50 \mathrm{nmol} / 1$ was present in $11 \%$ of the patients. The combination of a calcium intake of $<1000$ $\mathrm{mg} / \mathrm{d}$ and a serum $25(\mathrm{OH}) \mathrm{D}$ of $<50 \mathrm{nmol} / \mathrm{l}$ was present in $43 \%$ of the patients (Figure 2). None of the patients had a calcium intake of $\geq 1200 \mathrm{mg} / \mathrm{d}$ together with serum $25(\mathrm{OH}) \mathrm{D}$ levels of $\geq 75 \mathrm{nmol} / \mathrm{l}$. We checked the representativity of the participating population. Patients in the non-participating group were significantly older (74 years versus 70 years, $\mathrm{p}<0.001)$ and had more major $(35 \%$ versus $30 \%, \mathrm{p}<0.001)$ and hip fractures $(18 \%$ versus $8 \%, p<0.001)$ compared to the patients that were eligible for this study.

\subsection{Calcium Intake}

The individualized doses of calcium supplementation

Table 1. Patient characteristics $(n=502)$.

\begin{tabular}{cccc}
\hline & Mean & SD & Range \\
\hline Age (yrs) & 70 & 11 & 49 to 97 \\
Weight (kg) & 70 & 13 & 40 to 130 \\
Calcium intake (mg/d) & 839 & 295 & 250 to 2050 \\
Serum 25(OH)D (nmol/1) & 43 & 23 & $<10$ to 130 \\
T-score Spine & -1.7 & 1.3 & -5.3 to 3.6 \\
Total hip & -1.2 & 1.2 & -4.3 to 2.6 \\
Femoral neck & -1.6 & 1.1 & -4.6 to 2.3 \\
Osteoporosis (n, \%) & $189(38 \%)$ & & \\
Osteopenia (n, \%) & $233(46 \%)$ & & \\
Normal BMD (n, \%) & $80(16 \%)$ & & \\
\hline
\end{tabular}

SD: standard deviation.

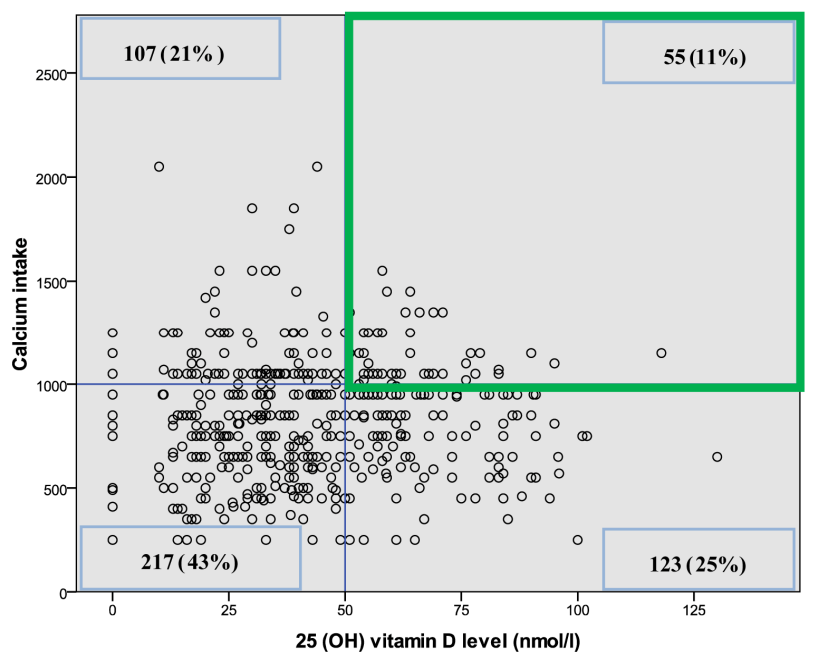

Figure 2. Baseline daily calcium intake and serum 25-hydroxyvitamin $D$ levels in $\mathbf{5 0 2}$ patients older than 50 years at the time they present with a fracture. Number and \% of patients are given for the four quadrants. Only $55(11 \%)$ patients achieved a daily calcium intake $\geq 1000 \mathrm{mg} / \mathrm{day}$ and a $25(\mathrm{OH}) D$ level $\geq 50 \mathrm{nmol} / \mathrm{l}$ (green quadrant). needed to achieve several desirable levels of total daily calcium intake based on baseline calcium intake are shown in Figure 3 (panels (a) and (b)).

In order to achieve an individualized total daily calcium intake of $\geq 1000 \mathrm{mg} / \mathrm{d}, 31 \%$ needed no calcium supplements, $57 \%$ needed supplementation of $500 \mathrm{mg} / \mathrm{d}$ and $12 \%$ needed $1000 \mathrm{mg} / \mathrm{d}$. In order to achieve an individualized daily calcium intake of $\geq 1200 \mathrm{mg} / \mathrm{d}, 9 \%$ needed no supplements, $59 \%$ needed $500 \mathrm{mg} / \mathrm{d}$ and $32 \%$ needed $1000 \mathrm{mg} / \mathrm{d}$. To achieve an individualized intake of $1500 \mathrm{mg} / \mathrm{d}, 31 \%$ needed $500 \mathrm{mg} / \mathrm{d}, 57 \%$ needed 1000 $\mathrm{mg} / \mathrm{d}$ and $12 \%$ needed $1500 \mathrm{mg} / \mathrm{d}$ of calcium supple-

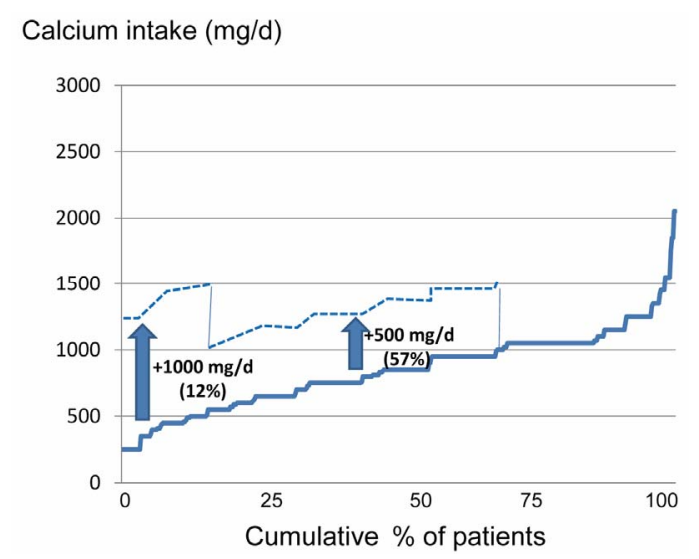

(a)

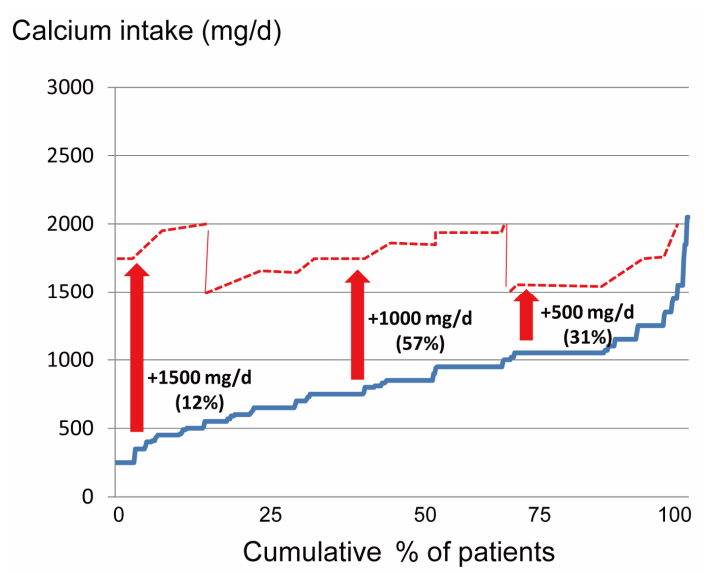

(b)

Figure 3. Effect of applying an individualized calcium dose supplementation strategy in order to achieve a total daily calcium intake of $\geq 1000 \mathrm{mg} / \mathrm{d}$ (panel (a)) and of $\geq 1500 \mathrm{mg} / \mathrm{d}$ (panel (b)) in patients older than 50 years with a fracture. Blue line: \% of patients (X-axis) with the total amount of daily calcium intake (mg/day) at baseline (Y-axis). Blue dotted line: total daily calcium intake when using an individualized calcium dose supplementation strategy in order to achieve a total daily calcium intake of $\geq 1000 \mathrm{mg} / \mathrm{d}$ in all patients. Red dotted line: total daily calcium intake when using an individualized calcium dose supplementation strategy in order to achieve a total daily calcium intake of $\geq 1500 \mathrm{mg} / \mathrm{d}$ in all patients. 
mentation.

When applying an individualized calcium dose supplementation strategy in order to achieve a total daily calcium intake of $\geq 1000 \mathrm{mg} / \mathrm{d}$ in all patients, only $1 \%$ of the patients would surpass a total daily intake $\geq 1500$ $\mathrm{mg} / \mathrm{d}$. These patients already had an intake $\geq 1500 \mathrm{mg} / \mathrm{d}$ at baseline. When aiming at an individualized total daily calcium intake $\geq 1200 \mathrm{mg} / \mathrm{d}$, half of the patients who needed $1000 \mathrm{mg} / \mathrm{d}$ calcium supplementation to achieve this goal would surpass $1500 \mathrm{mg} / \mathrm{d}$. In the patients that needed $500 \mathrm{mg} / \mathrm{d}$ calcium supplementation in order to achieve a total daily calcium intake $\geq 1200 \mathrm{mg} / \mathrm{d}, 37 \%$ would also surpass $1500 \mathrm{mg} / \mathrm{d}$.

If patients systematically would be supplemented with a fixed calcium dose of $500 \mathrm{mg} / \mathrm{d}, 85 \%$ would achieve a total daily calcium intake of $1000 \mathrm{mg} / \mathrm{d}, 67 \%$ of the patients would achieve an intake of $\geq 1200 \mathrm{mg} / \mathrm{d}$ and $31 \%$ of the patients would surpass a total daily calcium intake of $1500 \mathrm{mg} / \mathrm{d}$. If patients systematically would be supplemented with a fixed calcium dose of $1000 \mathrm{mg} / \mathrm{d}$, all would achieve an intake of $1000 \mathrm{mg} / \mathrm{d}$ and $1200 \mathrm{mg} / \mathrm{d}$, and $88 \%$ of the patients would achieve a total calcium intake above $1500 \mathrm{mg} / \mathrm{d}$ (Figure 4).

Only sex was a risk factor for low calcium intake at baseline: mean calcium intake was lower in men than in women (B: $-116,95 \%$ confidence interval $(\mathrm{CI})$ : -179 , -53 ). Calcium intake did not differ according to age (B: -0.4 , CI: $-3.0,-2.2$ ), total hip BMD (B: -6.7 , CI -20.4 , 33.9) or fracture locations (overall $\mathrm{p}=0.348$ ), i.e. low calcium intake was as frequent in younger as in older patients, at all levels of BMD and at all fracture locations.

\subsection{Serum 25(OH)D}

In order to achieve an individualized serum 25(OH)D

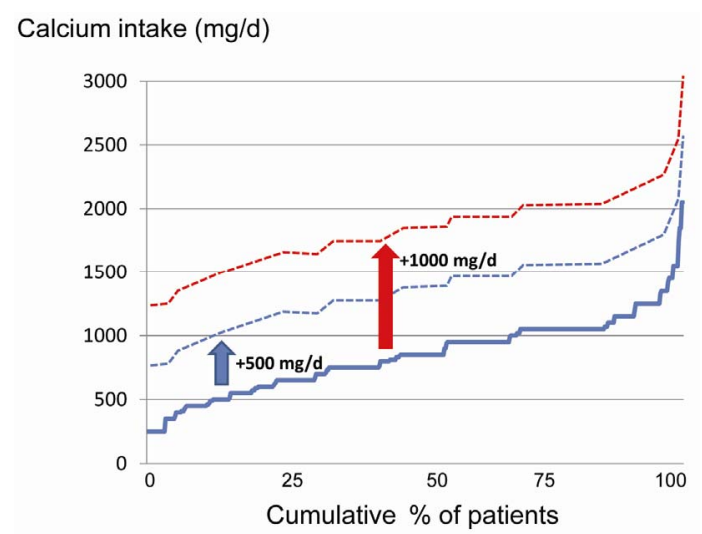

Figure 4. Achieved total amount of daily calcium intake when using a systematic fixed supplementation of $500 \mathrm{mg}$ (blue dotted line) and $1000 \mathrm{mg}$ (red dotted line) calcium per day in patients older than 50 years with a fracture. Blue line: cumulative $\%$ of patients $(\mathrm{X}$-axis) with the total amount of daily calcium intake (mg/day) at baseline (Y-axis). level of $50 \mathrm{nmol} / \mathrm{l}, 34 \%$ of the patients did not need vitamin D supplementation, $41 \%$ of patients needed 400 $800 \mathrm{IU} / \mathrm{d}$ vitamin D3, 17\% needed $1200 \mathrm{IU}$ D3/d and 9\% needed 1600 IU D3/d (Figure 5 panels (a)-(c)). To achieve an individualized calculated serum level of $75 \mathrm{nmol} / \mathrm{l}$, $10 \%$ did not need D3 supplements, $22 \%$ needed $800 \mathrm{IU}$ D3/d, 19\% needed $1200 \mathrm{IU} / \mathrm{d}, 20 \%$ needed 1600 or 2000 IU/d and $9 \%$ needed $2400 \mathrm{IU} / \mathrm{d}$. To achieve an individualized calculated serum level of $100 \mathrm{nmol} / \mathrm{l}, 5 \%$ needed $800 \mathrm{IU} / \mathrm{d}, 11 \%$ needed $1200 \mathrm{IU} / \mathrm{d}, 16 \%$ needed $1600 \mathrm{IU} / \mathrm{d}, 19 \%$ needed $2000 \mathrm{IU} / \mathrm{d}, 20 \%$ needed 2400 IU/d and $28 \%$ needed higher doses than $2400 \mathrm{IU} / \mathrm{d}$.

If all patients systematically were prescribed supplements of $800 \mathrm{IU} \mathrm{D} 3 / \mathrm{d}, 75 \%$ of the patients would achieve a level $\geq 50 \mathrm{nmol} / 1,33 \%$ a level $\geq 75 \mathrm{nmol} / 1$ and $9 \%$ a level $\geq 100 \mathrm{nmol} / 1$ (Figure 6). If all patients systematiccally were prescibed supplements of $2000 \mathrm{IU}$ D3/d, all patients would achieve levels $\geq 50 \mathrm{nmol} / 1,90 \%$ a level $\geq 75 \mathrm{nmol} / \mathrm{l}$ and $50 \%$ a level $\geq 100 \mathrm{nmol} / 1$. None of the calculated individualized or systematic vitamin D supplements would bring serum 25(OH)D above the toxic level of $220 \mathrm{nmol} / \mathrm{l}$.

Risk factors for low serum $25(\mathrm{OH}) \mathrm{D}$ were being female (B: 5.6, CI 0.8, 10.5), increasing age (B -0.5 , CI: $-0.3,-0.7)$ and low BMD (B: -2.9 , CI: $-0.7,-4.9$ ). Mean serum 25(OH)D was similar between major, minor or finger and toe fractures (overall $\mathrm{p}=0.575$ ).

Mean serum levels of $25(\mathrm{OH}) \mathrm{D}$ significantly varied during the year, being lowest in January $(28 \mathrm{nmol} / \mathrm{l}$, range: 0 - $66 \mathrm{nmol} / \mathrm{l})$ and highest in August $(55 \mathrm{nmol} / \mathrm{l}$, range: $16-95 \mathrm{nmol} / \mathrm{l})(\mathrm{p}<0.0001$ by ANOVA).

\section{Discussion}

The baseline levels of calcium intake and serum 25 $(\mathrm{OH}) \mathrm{D}$ varied widely between fracture patients. Consequently, the need and amount of supplements varied between fracture patients.

A combination of adequate calcium intake and serum $25(\mathrm{OH}) \mathrm{D}$ was low, even if the most conservative levels were considered: only $11 \%$ of patients had a calcium intake of $\geq 1000 \mathrm{mg} / \mathrm{d}$ and serum $25(\mathrm{OH}) \mathrm{D}$ of $\geq 50 \mathrm{nmol} / \mathrm{l}$, indicating that the large majority of patients needed calcium and/or vitamin D supplements according to currently available guidelines. These results confirm that vitamin D deficiency is endemic in the Netherlands (as elsewhere in most parts of the world), and that the combination of vitamin D deficiency with insufficient calcium intake is common in fracture patients, at least in the Netherlands. However, the doses of needed calcium and vitamin D supplements is not only guided by baseline levels, but also by desirable levels, upper safety levels and the decision of application of individually titrated or fixed supplements to all fracture patients. As a result, 


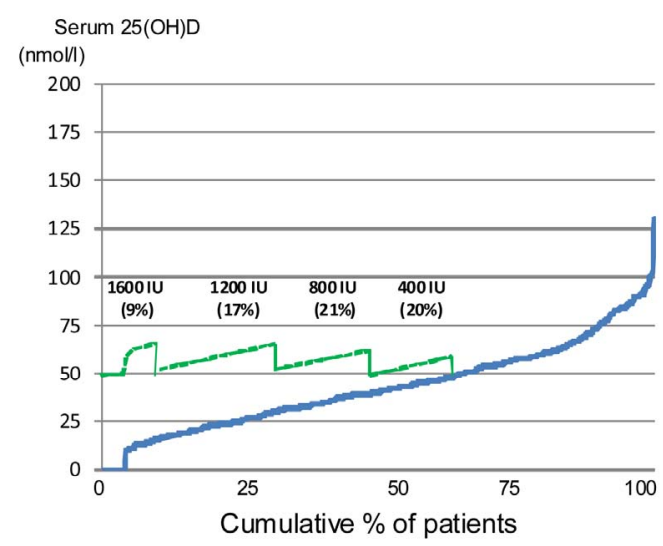

(a)

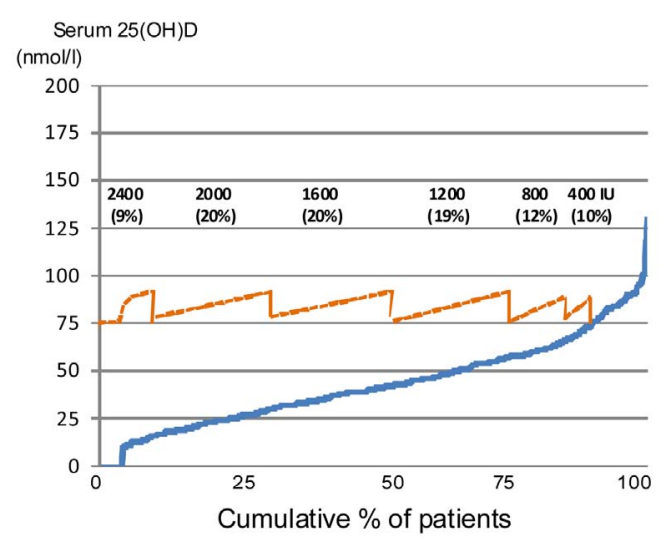

(b)

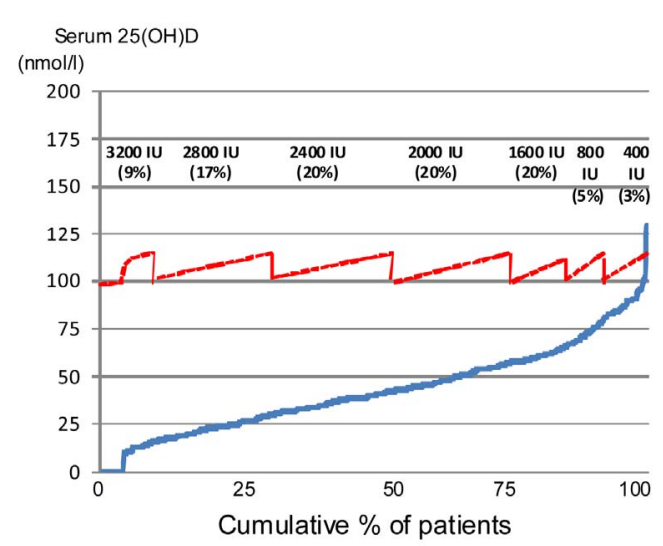

(c)

Figure 5. Effect of applying an individualized supplemental $D 3$ dose in order to achieve a desired serum 25(OH)D level: $\geq 50 \mathrm{nmol} / \mathrm{l}$ (green line) in panel (a), $\geq 75 \mathrm{nmol} / \mathrm{l}$ (orange line) in panel (b) and $\geq \mathbf{1 0 0} \mathrm{nmol} / \mathrm{l}$ (red line) in panel (c). Blue line: baseline values of serum $25(\mathrm{OH}) \mathrm{D}$ levels (Y-axis, $\mathrm{nmol} / \mathrm{l}$ ) in cumulative $\%$ of patients ( $\mathrm{X}$-axis).

calculation of adequate supplement doses in daily practice, whether individualized or at the group level, was much more complex than originally expected.

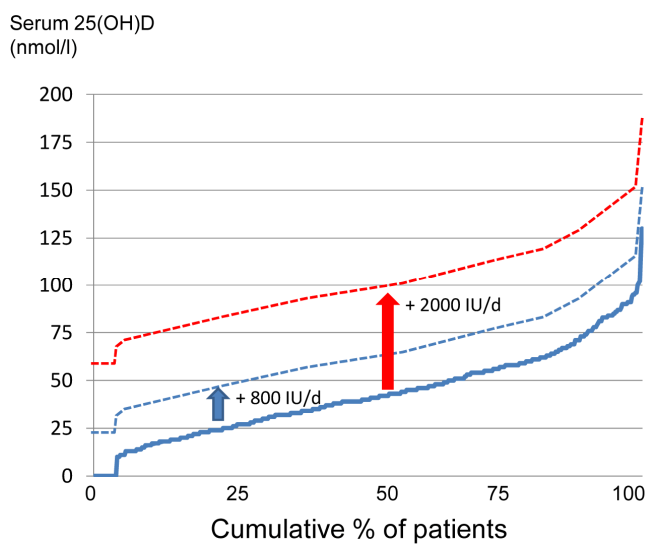

Figure 6. Achieved 25(OH) D levels when using a fixed supplemental D3 dose of 800 IU/d (blue dotted line) and 2000 IU/d (red dotted line). Blue line: baseline values of serum 25(OH)D levels ( $\mathrm{Y}$-axis, $\mathrm{nmol} / \mathrm{l})$ in cumulative \% of patients (X-axis).

\subsection{Calcium}

The baseline calcium intake, and therefore also the need for calcium supplementation, was very heterogeneous in fracture patients. Mean calcium intake was lower in men than in women, but was not related to age, BMD, or baseline fracture location. This indicates that calcium intake should be checked in all fracture patients, and when necessary, the calcium intake should be increased by diet or supplements.

In order to achieve individualized total calcium intakes between 1000 and $1500 \mathrm{mg} / \mathrm{d}, 12 \%$ needed $1000 \mathrm{mg} / \mathrm{d}$, $57 \%$ needed $500 \mathrm{mg} / \mathrm{d}$ and $31 \%$ needed no calcium supplements. In order to achieve calcium intake between 1500 and $2000 \mathrm{mg} / \mathrm{d}, 12 \%$ needed $1500 \mathrm{mg} / \mathrm{d}, 57 \%$ needed $1000 \mathrm{mg} / \mathrm{d}$ and $31 \%$ needed $500 \mathrm{mg} / \mathrm{d}$ of calcium supplements.

Prescribing a fixed supplement dose of $500 \mathrm{mg} / \mathrm{d}$ of calcium would be insufficient to achieve an intake of $1000 \mathrm{mg} / \mathrm{d}$ in $12 \%$ of the fracture patients, but it would raise the calcium intake to $1000-1500 \mathrm{mg} / \mathrm{d}$ in $57 \%$, and to $\geq 1500 \mathrm{mg} / \mathrm{d}$ in $31 \%$ of fracture patients. In fracture patients, a fixed supplement dose of $1000 \mathrm{mg} / \mathrm{d}$ would raise the total calcium intake to $1000-1500 \mathrm{mg} / \mathrm{d}$ in $12 \%$, to $1500-2000 \mathrm{mg} / \mathrm{d}$ in $57 \%$ and to $\geq 2000 \mathrm{mg} / \mathrm{d}$ in $31 \%$ of them.

The upper maximal limit for calcium intake is unclear and a matter of debate [42,43]. From a physiological point of view, an intake of more than $1200 \mathrm{mg} / \mathrm{d}$, especially more than $1500 \mathrm{mg} / \mathrm{d}$, does not further increase net calcium absorption in combination with adequate vitamin D supplementation, and therefore is considered unnecessary [44]. In terms of safety, the upper limit of intake is considered 1500 - $2500 \mathrm{mg} / \mathrm{d}$ [22,27,45]. However, an intake of more than $1200 \mathrm{mg} / \mathrm{d}$ is already considered as possibly unsafe in view of the possibility of increased 
risk of CV events [12]. The increased risk of CV events has been shown in healthy postmenopausal women and men with a mean baseline intake of $800 \mathrm{mg} / \mathrm{d}$, who received calcium supplement of $1000 \mathrm{mg} / \mathrm{d}[46,47]$. However, such side effects were not found in other studies and were not prospectively studied as primary or secondary endpoint [48], which still leaves open the question as to which is a safe upper level of calcium intake [42, 43].

In daily practice, taking into account the guidelines, calcium supplements should be titrated individually in order to achieve a total calcium intake between 1000 and $1500 \mathrm{mg} / \mathrm{d}$ in all patients. In our study this can be achieved easily with calcium supplements of $1000 \mathrm{mg} / \mathrm{d}$ in $12 \%$ of the patients with lowest baseline calcium intake and with $500 \mathrm{mg} / \mathrm{d}$ in $56 \%$ of the patients with moderate baseline calcium intake, while $31 \%$ did not need calcium supplementation. It is of interest that cross-sectional studies show that a neutral calcium balance is achieved at an intake of $741 \mathrm{mg} /$ day of calcium [15]; and that, if vitamin $\mathrm{D}$ serum levels are adequate, the need of total calcium intake would be lower than $1000 \mathrm{mg} / \mathrm{d}$ [44]. However, such hypotheses still need to be tested prospectively.

\subsection{Vitamin D}

The baseline levels of $25(\mathrm{OH}) \mathrm{D}$, and therefore, the need of vitamin D supplementation was also very heterogeneous in fracture patients. Lowest serum levels of 25(OH)D were found in elderly ( $>70$ years) fracture patients with osteoporosis, in patients with a hip fracture, in $50-70$ year old patients, during winter and summer time and in patients with other fractures than hip fractures, indicating the need for vitamin D supplements in all fracture patients.

In order to achieve serum levels of $\geq 50 \mathrm{nmol} / 1$ in all patients, more than half of the patients needed individually titrated doses between 400 en $1600 \mathrm{IU}$ D3/d. In order to achieve serum levels of $\geq 75 \mathrm{nmol} / 1$ in all patients, $90 \%$ of the patients needed individually titrated doses between 800 en $2400 \mathrm{IU}$ D3/d. In order to achieve serum levels of $100 \mathrm{nmol} / \mathrm{l}$, all patients needed individually titrated doses between 800 en 3200 IU D3/d.

In fracture patients, a fixed daily vitamin $\mathrm{D}$ dose of $800 \mathrm{IU}$ D3 would be sufficient to reach $50 \mathrm{nmol} / 1$ in $75 \%$, to reach $75 \mathrm{nmol} / 1$ in $33 \%$ and to reach $100 \mathrm{nmol} / 1$ only in $9 \%$ of the patients, respectively. A fixed daily vitamin D dose of 2000 IU D3 would be sufficient to reach 50 $\mathrm{nmol} / \mathrm{l}$ in all, but insufficient to reach $75 \mathrm{nmol} / 1$ in $10 \%$ and insufficient to reach $100 \mathrm{nmol} / \mathrm{l}$ in $50 \%$ of the patients.

None of the above mentioned individually titrated doses (400 to 3200 IU D3 daily) or fixed doses (800 to
2000 IU D3 daily) would raise serum levels of 25(OH)D above the toxic level of $220 \mathrm{nmol} / \mathrm{l}$.

Therefore, based on the guidelines, the simplest clinically decision for most fracture patients would be to systematically prescribe $800 \mathrm{IU}$ D3/d if the desirable level is $50 \mathrm{nmol} / 1$ and $2000 \mathrm{IU} \mathrm{D} 3 / \mathrm{d}$ if the desirable level is 75 $\mathrm{nmol} / \mathrm{l}$, without needing measurements of baseline serum levels of $25(\mathrm{OH}) \mathrm{D}$. However, the cost of this approach needs to be compared with the cost of measuring $25(\mathrm{OH}) \mathrm{D}$ and individualized use of appropriate calculated D3 doses.

Some experts argued that a fixed dose of vitamin D is sufficient [45], while others argued that the achieved serum level is crucial $[38,44]$. Another point of uncertainty is how long these doses of supplementation are needed. Presumably, it takes two to three months to achieve desirable serum levels $[38,40,49]$. However, it is unclear if at that time a follow-up measurement of serum $25(\mathrm{OH}) \mathrm{D}$ is indicated and how the dose can be adapted based on this follow-up measurement. Therefore, there is need of dose-effect studies focusing on vitamin $\mathrm{D}$ supplementation based on baseline values $25(\mathrm{OH}) \mathrm{D}$ levels, desirable serum levels and dose adaptation during follow up according to new measurements of serum $25(\mathrm{OH}) \mathrm{D}$ levels.

This study has several limitations. Firstly, the need of calcium and vitamin D supplements was calculated and not prospectively evaluated. Our analysis however tried to give considerations for current clinical practice based on current available guidelines, in attendance of prospective dose finding studies on this subject. Patients were treated with $800 \mathrm{IU}$ D3/d without further measurement of serum 25(OH)D concentration, according to current guidelines in the Netherlands [50].

Secondly, the calculation of vitamin D supplements was based on the results of meta-analyses on dose-effect studies $[38,44]$. For calculating the effect of vitamin D3 supplementation on serum $25(\mathrm{OH}) \mathrm{D}$ concentration, a rise of the $25(\mathrm{OH}) \mathrm{D}$ level with $1.2 \mathrm{nmol} / 1$ for each $40 \mathrm{IU}$ supplemental D3/d was taken into account, based on results found in patients with baseline values $<50 \mathrm{nmol} / 1$ $[38,44]$. In patients with baseline serum $25(\mathrm{OH}) \mathrm{D}>50$ $\mathrm{nmol} / \mathrm{l}$, the increase of $25(\mathrm{OH}) \mathrm{D}$ level would be 0.6 $\mathrm{nmol} / \mathrm{l}$ per $40 \mathrm{IU}$ supplemental D3/d, and therefore, these patients would have a more modest increase than patients with lower baseline intakes. However, there is a lack of studies with a randomized prospective design, specifically analyzing dose-effect of vitamin D3.

Thirdly, sun exposition and artificial UV exposition are other ways to provide supplements of vitamin D. These were not taken into account as the exact timing and dose of such ways of supplementation is unclear and difficult to evaluate in clinical practice [13].

Fourthly, only $58 \%$ of all fracture patients participated 
in the analysis. As in other studies, participation of fracture patients in follow up programs is low, which can be explained by early dead, dementia, co-morbidity, personal reasons, and decisions of family members, especially in the elderly [51]. There is need to improve this low response of fracture patients, as many patients with high fracture risk, such as after a hip fracture, are probably even more deficient in calcium and vitamin D intake [24].

Fifthly, the results of this study cannot be generalized to other countries, since the mean calcium intake and serum $25(\mathrm{OH}) \mathrm{D}$ concentrations are low in fracture patients in the Netherlands compared with other countries $[5,19]$. In the US, calcium intake is deficient [16], but intake of vitamin D3 supplements is higher than in Europe, because the allowed dosage of vitamin D3 in food is higher compared with European countries [12]. Therefore, the prescribed dosage of calcium and vitamin D3 supplements in fracture patients need to be adapted to regional baseline status of calcium intake and serum $25(\mathrm{OH}) \mathrm{D}$. Furthermore, no calculations were made for vitamin D2 supplementation. This should also be calculated for countries were only vitamin D2 is available for supplementation.

In conclusion, the results of this study indicate that baseline values of calcium intake and baseline serum levels of $25(\mathrm{OH}) \mathrm{D}$ vary considerably in fracture patients. Taking into account desirable and safety amounts of calcium intake, desirable and safety serum levels of 25 $(\mathrm{OH}) \mathrm{D}$, the amounts of supplements to be given and the choice between individualized or systematic use of different doses, all these factors have to be carefully considered by the clinician who takes care of fracture patients. We propose that calcium and vitamin D supplements should be titrated on an individual basis according to the baseline values in combination with desirable need and safety levels. Supplementation of fixed dosages of D3 may result in suboptimal levels of vitamin D and fixed dosages of calcium may result in very high calcium intake, especially with a fixed dose of $1000 \mathrm{mg}$ calcium. Further longitudinal studies are needed to answer questions regarding how to achieve and maintain optimal serum vitamin D levels and adequate calcium intake in fracture patients with either titrated or systematic fixed supplementation calcium and vitamin D dosages.

\section{REFERENCES}

[1] J. R. Center, D. Bliuc, T. V. Nguyen and J. A. Eisman, "Risk of Subsequent Fracture after Low-Trauma Fracture in Men and Women," Journal American Medical Association, Vol. 297, No. 4, 2007, pp. 387-394. doi:10.1001/jama.297.4.387

[2] A. C. M. van Geel, P. Geusens, I. F. Nagtzaam, C. M. J. R. Schreurs, D. J. M. van der Voort, P. E. L. M. Rinkens,
A. D. M. Kester and G. J. Dinant, "Timing and Risk Factors of Clinical Fractures among Postmenopausal Women: A 5-Year Prospective Study," BMC Medicine, Vol. 4, 2006, p. 24.

[3] A. C. M. van Geel, S. van Helden, P. P. Geusens, B. Winkens and G. J. Dinant, "Clinical Subsequent Fractures Cluster in Time after First Fractures," Annals Rheumatic Diseases, Vol. 68, No. 1, 2009, pp. 99-102. doi:10.1136/ard.2008.092775

[4] S. van Helden, J. Cals, F. Kessels, P. Brink, G. J. Dinant and P. Geusens, "Risk of New Clinical Fractures within 2 Years Following a Fracture," Osteoporosis International, Vol. 17, No. 3, 2006, pp. 348-354. doi:10.1007/s00198-005-2026-X

[5] S. van Helden, A. C. M. van Geel, P. P. Geusens, A. Kessels, A. C. Nieuwenhuijzen Kruseman and P. R. Brink, "Bone and Fall-Related Fracture Risks in Women and Men with a Recent Clinical Fracture," Journal Bone Joint Surgery American, Vol. 90, No. 2, 2008, pp. 241-248. doi:10.2106/JBJS.G.00150

[6] J. A. Kanis, E. V. McCloskey, H. Johansson, O. Strom, F. Borgstrom and A. Oden, "Case Finding for the Management of Osteoporosis with FRAX-Assessment and Intervention Thresholds for the UK," Osteoporosis International, Vol. 19, No. 10, 2008, pp. 1395-1408. doi:10.1007/s00198-008-0712-1

[7] R. L. Lindsay, S. L. Silverman, C. Cooper, D. A. Hanley, I Barton, S. B. Broy, A. Licata, L. Benhamou, P. Geusens, K. Flowers, et al., "Risk of New Vertebral Fracture in the Year Following a Fracture," Journal American Medical Association, Vol. 285, No. 3, 2001, pp. 320-323. doi:10.1001/jama.285.3.320

[8] J. Ryg, L. Rejnmark, S. Overgaard, K. Brixen and P. Vestergaard, "Hip Fracture Patients at Risk of Second Hip Fracture-A Nationwide Population-Based Cohort Study of 169,145 Cases during 1977-2001," Journal Bone Mineral Research, Vol. 24, No. 7, 2009, pp. 1299-1307. doi:10.1359/jbmr.090207

[9] P. P. Geusens, W. F. Lems, H. J. Verhaar, G. Leusink, S. Goemaere, H. Zmierczack and J. Compston, "Review and Evaluation of the Dutch Guidelines for Osteoporosis," Journal Evaluation Clinical Practice, Vol. 12, No. 5, 2006, pp. 539-548. doi:10.1111/j.1365-2753.2006.00647.x

[10] J. A. Kanis, N. Burlet, C. Cooper, P. D. Delmas, J. Y. Reginster, F. Borgstrom and R. Rizzoli, "European Guidance for the Diagnosis and Management of Osteoporosis in Postmenopausal Women," Osteoporosis International, Vol. 19, 2008, pp. 399-428. doi:10.1007/s00198-008-0560-Z

[11] J. A. Kanis, J. Compston, A. Cooper, C. Cooper, R. Francis, D. Marsh, E. V. McCloskey, D. Reid, P. Selby and M. Ilkins, "Guideline for the Diagnosis and Management of Osteoporosis in Postmenopausal Women and Men from the Age of 50 Years in the UK," World Health Organization Collaborating Centre for Metabolic Bone Diseases, University of Sheffield, Sheffield, 2009.

[12] Anonymous, "Clinician's Guide to Prevention and Treatment of Osteoporosis," 2012. 
http://www.nof.org/professionals/NOF_Clinicians_Guide. pdf

[13] J. Pfeilschifter, "2006 DVO-Guideline for Prevention, Diagnosis, and Therapy of Osteoporosis for Women after Menopause, for Men after Age 60 Executive Summary Guidelines," Experimental Clinical Endocrinology Diabetes, Vol. 114, No. 10, 2006, pp. 611-622.

[14] B. Dawson-Hughes, "Calcium and Vitamin D," In: C. Rosen, Ed., Primer on the Metabolic Bone Diseases and sordersof Mineral Metabolism, 7th Edition, American Society of Bone and Mineral Research, Washington, 2008, pp. 231-233. doi:10.1002/9780470623992.ch47

[15] C. D. Hunt and L. K. Johnson, "Calcium Requirements: New Estimations for Men and Women by Cross-Sectional Statistical Analyses of Calcium Balance Data from Metabolic Studies," American Journal Clinical Nutrition, Vol. 86, No. 4, 2007, pp. 1054-1063.

[16] J. Ma, R. A. Johns and R. S. Stafford, "Americans Are Not Meeting Current Calcium Recommendations," American Journal Clinical Nutrition, Vol. 85, No. 5, 2007, pp. 1361-1366.

[17] N. O. Kuchuk, N. M. van Schoor, S. M. Pluijm, A. Chines and P. Lips, "Vitamin D Status, Parathyroid Function, Bone Turnover, and BMD in Postmenopausal Women with Osteoporosis: Global Perspective," Journal Bone Mineral Research, Vol. 24, No. 4, 2009, pp. 693-701. doi:10.1359/jbmr.081209

[18] C. Tannenbaum, J. Clark, K. Schwartzman, S. Wallenstein, R. Lapinski, D. Meier and M. Luckey, "Yield of Laboratory Testing to Identify Secondary Contributors to Osteoporosis in Otherwise Healthy Women," Journal Clinical Endocrinology Metabolism, Vol. 87, No. 10, 2002, pp. 4431-4437. doi:10.1210/jc.2002-020275

[19] B. Dumitrescu, S. van Helden, R. ten Broeke, A. Nieuwenhuijzen Kruseman, C. Wyers, G. Udrea, S. van der Linden and P. Geusens, "Evaluation of Patients with a Recent Clinical Fracture and Osteoporosis, a Multidisciplinary Approach," BMC Musculoskeletal Disorders, Vol. 9, 2008, p. 109. doi:10.1186/1471-2474-9-109

[20] Anonymous, "Dietary Supplement Fact Sheet: Vitamin D," Office of Dietary Supplements, National Institutes of Health, 2009. http://ods.od.nih.gov/factsheets/list-all/VitaminD/

[21] Standing Committee on the Scientific Evaluation of Dietary Reference Intakes FaNB, "Dietary Reference Intakes for Calcium, Phosphorus, Magnesium, Vitamin D, and Fluoride," National Academy Press, Washington, 1997.

[22] Anonymous, "Voedingsaanbevelingen Voor België," Hoge Gezondheidsraad, Brussel, 2009. http://www.kindengezin.be/img/voedingsaanbevelingenv oorbelgie2009.pdf

[23] H. A. Deutschmann, M. Weger, W. Weger, P. Kotanko, M. J. Deutschmann and F. Skrabal, "Search for Occult Secondary Osteoporosis: Impact of Identified Possible Risk Factors on Bone Mineral Density," Journal Internal Medicine, Vol. 252, No. 5, 2002, pp. 389-397. doi:10.1046/j.1365-2796.2002.01040.x

[24] C. Becker, S. Crow, J. Toman, C. Lipton, D. J. McMahon,
W. Macaulay and E. Siris, "Characteristics of Elderly Patients Admitted to an Urban Tertiary Care Hospital with Osteoporotic Fractures: Correlations with Risk Factors, Fracture Type, Gender and Ethnicity," Osteoporosis International, Vol. 17, No. 3, 2005, pp. 410-416.

[25] S. Gaugris, R. P. Heaney, S. Boonen, H. Kurth, J. D. Bentkover and S. S. Sen, "Vitamin D Inadequacy among Post-Menopausal Women: A Systematic Review," Quarterly Journal Medicine, Vol. 98, No. 9, 2005, pp. 667676. doi:10.1093/qimed/hci096

[26] B. J. Edwards, C. B. Langman, A. D. Bunta, M. Vicuna and M. Favus, "Secondary Contributors to Bone Loss in Osteoporosis Related Hip Fractures," Osteoporosis International, Vol. 19, No. 7, 2008, pp. 991-999. doi:10.1007/s00198-007-0525-7

[27] Anonymous, "Optimal Calcium Intake," National Institutes Health Consensus Statement, Vol. 12, No. 4, 1994, pp. 1-31.

[28] K. M. Sanders, C. A. Nowson, M. A. Kotowicz, K. Briffa, A. Devine and I. R. Reid, "Calcium and Bone Health: Position Statement for the Australian and New Zealand Bone and Mineral Society, Osteoporosis Australia and the Endocrine Society of Australia," Medical Journal Australia, Vol. 190, No. 6, 2009, pp. 316-320.

[29] J. P. Brown and R. G. Josse, "2002 Clinical Practice Guidelines for the Diagnosis and Management of Osteoporosis in Canada," Canadian Medical Association Journal, Vol. 167, No. 10, 2002, pp. S1-S34.

[30] Anonymous, "Management of Osteoporosis in Postmenopausal Women: 2010 Position Statement of the North American Menopause Society," Menopause, Vol. 17, No. 1, 2010, pp. 25-54.

[31] J. W. Nieves, "Osteoporosis: The Role of Micronutrients," American Journal Clinical Nutrition, Vol. 81, No. 5, 2005, pp. 1232s-1239s.

[32] R. P. Heaney, "The Vitamin D Requirement in Health and Disease," Journal Steroid Biochemical Molecular Biology, Vol. 97, No. 1-2, 2005, pp. 13-19.

[33] R. P. Heaney, "Vitamin D: Criteria for Safety and Efficacy," Nutrition Reviews, Vol. 66, No. 10, 2008, pp. S178-S181. doi:10.1111/j.1753-4887.2008.00102.x

[34] H. A. Bischoff Ferrari, "How to Select the Doses of Vitamin D in the Management of Osteoporosis," Osteoporosis International, Vol. 18, No. 4, 2007, pp. 401-407. doi:10.1007/s00198-006-0293-9

[35] P. P. Geusens, "Review of Guidelines for Testing and Treatment of Osteoporosis," Current Osteoporosis Reports, Vol. 1, No. 2, 2003, pp. 59-65.

[36] K. G. Saag and P. Geusens, "Progress in Osteoporosis and Fracture Prevention: Focus on Postmenopausal Women," Arthritis Research Therapy, Vol. 11, No. 5, 2009, p. 251. doi:10.1186/ar2815

[37] P. Geusens, P. Sambrook and W. Lems, "Fracture Prevention in Men," Nature Reviews Rheumatology, Vol. 5, No. 9, 2009, pp. 497-504. doi:10.1038/nrrheum.2009.148

[38] H. Bischoff Ferrari, "Vitamin D: What Is an Adequate Vitamin D Level and How Much Supplementation Is Necessary?" Best Practice Research Clinical Rheuma- 
tology, Vol. 23, No. 6, 2009, pp. 789-795. doi:10.1016/j.berh.2009.09.005

[39] J. N. Hathcock, A. Shao, R. Vieth and R. Heaney, "Risk Assessment for Vitamin D," American Journal Clinical Nutrition, Vol. 85, No. 1, 2007, pp. 6-18.

[40] M. F. Holick, "Vitamin D Deficiency," New England Journal Medicine, Vol. 357, No. 3, 2007, pp. 266-281. doi:10.1056/NEJMra070553

[41] Anonymous, “Assessment of Fracture Risk and Its Application to Screening for Postmenopausal Osteoporosis. Report of a WHO Study Group," World Health Organization Technical Report Series, Vol. 843, 1994, pp. 1129.

[42] Z. Sabbagh and H. Vatanparast, "Is Calcium Supplementation a Risk Factor for Cardiovascular Diseases in Older Women?" Nutrition Reviews, Vol. 67, No. 2, 2009, pp. 105-108. doi:10.1111/j.1753-4887.2008.00146.x

[43] N. A. Andrews, "Calcium Supplementation and Vascular Disease: A Legitimate New Worry?" International Bone Mineral Society BoneKEy, Vol. 5, No. 4, 2008, pp. 124129.

[44] R. P. Heaney, "Bone Health," American Journal Clinical Nutrition, Vol. 85, No. 1, 2007, pp. 300s-303s.

[45] R. M. Francis, "What Do We Currently Know about Nutrition and Bone Health in Relation to United Kingdom Public Health Policy with Particular Reference to Calcium and Vitamin D?" British Journal Nutrition, Vol. 99, No. 1, 2008, pp. 155-159. doi:10.1017/S0007114507791924
[46] M. J. Bolland, P. A. Barber, R. N. Doughty, B. Mason, A. Horne, R. Ames, G. D. Gamble, A. Grey and I. R. Reid, "Vascular Events in Healthy Older Women Receiving Calcium Supplementation: Randomised Controlled Trial," British Medical Journal, Vol. 336, No. 7638, 2008, pp. 262-266.

[47] I. R. Reid, R. Ames, B. Mason, H. E. Reid, C. J. Bacon, M. J. Bolland, G. D. Gamble, A. Grey and A. Horne, "Randomized Controlled Trial of Calcium Supplementation in Healthy, Nonosteoporotic, Older Men," Archives Internal Medicine, Vol. 168, No. 20, 2008, pp. 22762282. doi:10.1001/archinte.168.20.2276

[48] W. K. Al Delaimy, E. Rimm, W. C. Willett, M. J. Stampfer and F. B. Hu, "A Prospective Study of Calcium Intake from Diet and Supplements and Risk of Ischemic Heart Disease among Men," American Journal Clinical Nutrition, Vol. 77, No. 4, 2003, pp. 814-818.

[49] North-American-Menopause-Society, "Management of Osteoporosis in Postmenopausal Women: 2006 Position Statement of the North American Menopause Society," Menopause, Vol. 13, No. 3, 2006, pp. 340-367.

[50] Anonymous, "Guideline on Osteoporosis and Fracture Prevention," 2012. http://www.cbo.nl

[51] T. Chevalley, P. Hoffmeyer, J. P. Bonjour and R. Rizzoli, "An Osteoporosis Clinical Pathway for the Medical Management of Patients with Low-Trauma Fracture," Osteoporosis International, Vol. 13, 2002, pp. 450-455. doi: $10.1007 / \mathrm{s} 001980200053$ 